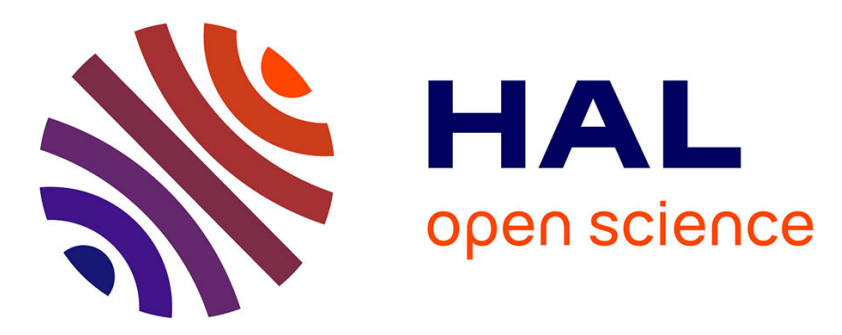

\title{
Tools providing new insight into coastal anoxygenic purple bacterial mats: review and perspectives
}

Cédric Hubas, Bruno Jesus, Claire Passarelli, Christian Jeanthon

\section{To cite this version:}

Cédric Hubas, Bruno Jesus, Claire Passarelli, Christian Jeanthon. Tools providing new insight into coastal anoxygenic purple bacterial mats: review and perspectives. Research in Microbiology, 2011, 162 (9), pp.858-868. 10.1016/j.resmic.2011.03.010 . hal-01140974

\section{HAL Id: hal-01140974 \\ https://hal.sorbonne-universite.fr/hal-01140974}

Submitted on 10 Apr 2015

HAL is a multi-disciplinary open access archive for the deposit and dissemination of scientific research documents, whether they are published or not. The documents may come from teaching and research institutions in France or abroad, or from public or private research centers.
L'archive ouverte pluridisciplinaire HAL, est destinée au dépôt et à la diffusion de documents scientifiques de niveau recherche, publiés ou non, émanant des établissements d'enseignement et de recherche français ou étrangers, des laboratoires publics ou privés. 
Tools providing new insight into coastal anoxygenic purple bacterial mats: review and perspectives

\author{
Cédric Hubas ${ }^{1}$, Bruno Jesus ${ }^{2,3}$, Claire Passarelli ${ }^{1}$, Christian Jeanthon ${ }^{4,5}$
}

1 - Muséum National d'Histoire Naturelle, UMR MNHN-CNRS-IRD-UPMC 7208 BOREA, CP 53, 61 rue Buffon, 75231 Paris Cedex 5, France

2 - Instituto de Oceanografia, Faculdade de Ciências de Lisboa, Campo Grande, 1749-016, Lisboa, Portugal

3 - Centro de Biodiversidade, Genómica Integrativa e Funcional (BioFIG), Faculdade de

Ciências, Universidade de Lisboa, Campo Grande, 1749-016 Lisboa, Portugal

4 - UPMC Univ Paris 06, UMR 7144, A daptation et Diversité en Milieu Marin, Station

Biologique de Roscoff, 29680 Roscoff, France

5 - CNRS, UMR 7144, Adaptation et Diversité en Milieu Marin, Station Biologique de Roscoff, 29680 Roscoff, France

Abstract: Coastal photosynthetic microbial mats are highly structured microbial communities that populate a variety of shallow environments such as estuaries, sheltered sandy beaches, intertidal flats, salt marshes or hypersaline salterns. In soft sediments, most of these microbial mats are formed of vertically stratified, multicolored and cohesive thin layers, of several functional groups of microorganisms, such as cyanobacteria, colorless sulfur bacteria, purple sulfur bacteria, or sulfate-reducing bacteria, distributed along vertical microgradients of oxygen, sulfide and light. These microbial communities are highly productive, significant contributors to carbon, nitrogen and sulfur cycles and to sediment stability in some shallowwater habitats. Many examples of these communities have been cited in the past, but comparatively few microbial mats have been presented where mass developments of anoxygenic purple bacteria have been observed. Yet, application of molecular approaches has provided fresh insight into the ecology, diversity and evolution of microbial mats. In situ measurements using electrochemical and optical microprobes allowed a d etailed characterization of the physical and chemical environment whereas reflectance measurements revealed the spatial or temporal heterogeneity of microbial mat surfaces. We hereby report the main discoveries made through the introduction of these powerful techniques and point out the potential insight that might be gained into the study of anoxygenic purple bacterial mats. 
Key words: microbial mats, anoxygenic phototrophs, sulfur purple bacteria, diversity, sediment stability, photosynthesis, spectral reflectance

\section{Introduction}

Microorganisms have the ability to colonize different types of habitats and interact with each other, forming more or less complex communities. Microbial mats that develop in different geographical locations are a remarkable example of these associations. They are found for instance in coral reefs, hypersaline ponds and lakes, salterns, thermal springs, Antarctic lakes, and coastal sediments (Stal and Caumette, 1994). In the latter, they develop at the sedimentwater interface in shallow environments such as estuaries, intertidal areas, sandy beaches or hypersaline salt marshes (Herbert, 1985, S tal and Caumette, 1994, V an Gemerden et al., 1989a, Van Gemerden et al., 1989b). Coastal microbial mats are principally inhabited by bacteria (heterotrophic, autotrophic and chemotrophic) as well as eukaryotic microalgae such as benthic diatoms. These consortia are often referred to as microbial mats, laminated microbial communities, microphytobenthos or simply biofilms, in the literature (or any combination) but describe ultimately the association of different microbial cells, embedded in an extracellular polymeric substance (EPS) matrix. These mats can exhibit different morphologies based on the physicochemical environments they experience. Most of the time, the cells are organized according to their physiologies in vertical laminated structure consisting of successive layers.

In the coastal zone, microbial mats are mostly photosynthetic and are composed of several functionally complementary groups of microorganisms whose composition can vary greatly depending on the energy and nutrient source from the top and bottom. Cyanobacteria are often the pioneer organisms and generally dominate the top layer. According to the chemical and light gradients available they can for instance be followed by aerobic or facultative heterotrophic bacteria, chemolithotrophic bacteria (among them colorless sulfur bacteria), anoxygenic phototrophs (purple and green) and sulfate-reducing bacteria, forming several laminated layers distributed within the EPS matrix principally produced by cyanobacteria. Purple bacteria perform anaerobic anoxygenic (without release of oxygen) photosynthesis as, unlike cyanobacteria, they are unable to perform water photolysis due to the lack of the photosystem II. They mostly use, as electron donors, the intermediate products of organic matter degradation from primary producers and some compounds originated from fermentation and anaerobic respiration. In microbial mats, a large diversity in purple bacteria 
is generally observed and the genus Thiocapsa is often highly represented (Van Gemerden et al., 1989b).

In the last decade, community structure as well as physical-chemical environment of the microbial mats have been reviewed at several occasions (Franks and Stolz, 2009, Paerl and Pinckney, 1996, S tal and Caumette, 1994, Van Gemerden, 1993). The introduction of molecular approaches has indeed provided new insight into the ecology of these mats by allowing the characterization of the community structure (Ranchou-Peyruse et al., 2006, Wieland et al., 2003). Thanks to the development of high resolution microelectrodes, the physical and chemical environment of these mats was characterized at very small spatial scales ( $\mu \mathrm{m}$ to mm, Revsbech and Jørgensen, 1983, Visscher et al., 1991). Pigment diversity and in situ reflectance measurements revealed the spatial or temporal heterogeneity of microbial mat surfaces (e.g. Brotas and Plante-Cuny, 2003, P aterson et al., 1998). Finally, their role in sediment biostabilisation was revealed (Paterson, 1997). This paper reports the main discoveries made through the introduction of these powerful techniques and points out the gap in current knowledge regarding anoxygenic phototrophic biofilms.

\section{Microbial communities in coastal purple phototrophic mats}

2.1. Structure of coastal purple phototrophic mats

Photosynthetic microbial mats develop in many different habitats with salinities ranging from freshwater to hypersaline conditions (Overmann and Garcia-Pichel, 2006, Van Gemerden, 1993). Some prominent marine and hypersaline habitats where laminated microbial communities frequently develop in visible masses are represented by coastal sediments of the Great Sippewissett salt marsh (USA) (Nicholson et al., 1987, Rothermich et al., 2000), coastal lagoons in the southern France (Caumette, 1986, Guyoneaud et al., 1996), marine salterns in France (Caumette et al., 1994, Giani et al., 1989) and in Guerrero Negro (Baja California, Mexico, (Canfield and Des Marais, 1993, Ley et al., 2006), sandy flats of the Ebro Delta (Mir et al., 1991, Navarrete et al., 2000), and sheltered beaches on the Orkney islands (Van Gemerden et al., 1989a, Van Gemerden et al., 1989b, W ieland et al., 2003). In such ecosystems, the surface sediment layer covers a transition zone between oxic and anoxic conditions characterized by steep gradients of oxygen and sulfide. These gradients favor the maturation of vertically stratified, multicolored and cohesive layers of several functional 
groups of microorganisms. Although the uppermost layer, brown and green in color, may contain benthic diatoms, the dense top material is typically formed by unicellular and filamentous cells of cyanobacteria that are generally the driving force as they provide growth substrates for other organisms. For instance, newly colonized sands mostly comprised Oscillatoria sp. and Spirulina sp. (Franks and Stolz, 2009). The gliding cyanobacterium Microcoleus chthonoplastes often replaces these pioneer species and becomes dominant in mature intertidal mats (Stal et al., 1985, V an Gemerden, 1993). Below the cyanobacteria, a distinct layer of purple sulfur bacteria is often present, sometimes overlying a layer of green sulfur bacteria. Sometimes, a white layer or patches due to sulfide-oxidizing bacteria (including Beggiatoa spp.) are visible at the surface of marine sediments that have a sufficiently high production of sulfide from bacterial sulfate reduction (Jorgensen, 1977). They are followed vertically by sulfate-reducing bacteria whose activity leads to the precipitation of iron sulfides visible as black mud. Aerobic heterotrophic organisms are also functionally important as their activity leads to oxygen depletion, and fermentative organisms provide growth substrates for sulfate-reducers. Other, numerically less important groups are nitrifying and denitrifying bacteria and methanogens. Numerous examples have been described in the literature of colored blooms and mass accumulations of phototrophic bacteria in the coastal zones and lagoons (Caumette and Baleux, 1980, Imhoff, 2001, and references herein). Mass developments of purple sulfur bacteria have been observed during warm summer months in the intertidal zone of sandy beaches (Herbert, 1985, V an Gemerden et al., 1989a, Van Gemerden et al., 1989b). Three different laminated microbial mats were described, distinguished by the position of the cyanobacterial layer above or beneath the purple sulfur bacterial layer, or its complete absence and therefore exclusive development of purple sulfur bacteria in the top layer. On the Orkney islands (Herbert, 1985, Van Gemerden et al., 1989a, Van Gemerden et al., 1989b) and in Roscoff Aber Bay (Fig. 1; Hubas, C., Jesus B. M., Jeanthon, C., unpublished data), the latter pattern occurs seasonally when beaches are supplied with a high load of organic matter due to decomposition of macroalgae. These purple sulfur bacteria are therefore almost permanently exposed to oxygen at the sediment surface (e.g. Herbert and Welsh, 1994). Among the purple bacteria, the purple nonsulfur bacteria are also widely distributed in aquatic environments rich in organic matter (Guyoneaud et al., 1996, Hiraishi and Ueda, 1995). 
2.2. Cultural and molecular diversity of purple sulfur phototrophic mats

Most ecological studies on the distribution of anoxygenic phototrophs in natural environments have been based on biochemical features such as photopigment composition (see section 3.1) and / or on estimations of bacterial numbers, isolation and characterization of pure cultures (Guyoneaud et al., 1996, Nicholson et al., 1987, Ranchou-Peyruse et al., 2006, Van Gemerden et al., 1989a). The most prominent purple sulfur bacteria, frequently observed and also isolated from marine coastal sediments, have been reviewed by van Gemerden and Mas (1995) and by Imhoff (2001). They were assigned to Thiocapsa roseopersicina, Thiocystis violacea and Allochromatium vinosum. As an example, various organisms have been cultivated from microbial mat communities of the Ebro Delta, one site among the most intensively studied. Vacuolated bacteria, such as Thiocapsa rosea and Lamprobacter modestohalophilus as well as non vacuolated bacteria such as Marichromatium gracile, T. roseopersicina or Ectothiorhodospira sp. have been isolated (Martinez-Alonso et al., 2005, Villanueva et al., 2010). T. roseopersicina, which is easily cultivated, is very common in marine coastal habitats and predominant in most systems where it can reach abundances of $10^{6}$ to $10^{7}$ cells.cm ${ }^{-3}$ (Van Gemerden et al., 1989a).. The adaptation to a wide range of salinities and the high metabolic versatility and flexibility of this organism (tolerance to oxygen and possible aerobic growth in the dark) are important competitive advantages that explain the success of its distribution (de Wit and van Gemerden, 1987 , de Wit and van Gemerden, 1990). Allochromatium spp and Marichromatium spp are also often observed and may be locally dominant (Imhoff, 2001). From red layers found in mats of hypersaline environments, other members of the family Chromatiaceae such as Halochromatium salexigens, H. glycolicum and Halothiocapsa halophila have also been isolated (Caumette et al., 1988, 1991, Caumette et al., 1997).

In the last decades, the species composition of microbial mats has mostly been described by dissecting cores into thin horizontal layers and extracting nucleic acids or other cell components for chemical and molecular analysis (Martinez-Alonso et al., 2005, Mouné et al., 2003, Navarrete et al., 2000, Ranchou-Peyruse et al., 2006, Villanueva et al., 2010). With these techniques, a high degree of bacterial diversity was generally found. As an example, the microbial mats within hypersaline lagoons at Guerrero Negro generated more than $150016 \mathrm{~S}$ rRNA sequences representing over 750 species (Ley et al., 2006). Denaturing gradient gel electrophoresis separation of $16 \mathrm{~S}$ rRNA gene amplification products obtained using specific primer combination for Chromatiaceae, the main family of purple sulfur bacteria, showed that 
the diversity of members of this family in microbial mats in the Ebro Delta was high and pointed out the presence of novel species not related to any known purple sulfur bacteria (Martinez-Alonso et al., 2005).

The pufM gene encodes for the medium (M) subunit of the photosynthetic reaction center of the anoxygenic photosynthetic bacteria of the Alpha-, Beta-, and Gammaproteobacteria and of the Chloroflexaceae. Molecular analyses using this functional gene have also been applied in order to specifically study the depth distribution of anoxygenic phototrophs in mat communities (Fourçans et al., 2004, W ieland et al., 2003). Using this method, vertical diel migration of an anoxygenic phototrophic community in responses to oxygen concentrations and $\mathrm{pH}$ was detected at a microscale depth level (Fourçans et al., 2006). Only few studies detailed the diversity of anaerobic purple bacteria by the analysis of pufM environmental libraries since the pioneering work of Achenbach et al. (2001) and Karr et al. (2003) on Antarctic lake waters and mats. An environmental clone library of the pufM gene was obtained from a thin cyanobacterial mat developed at the top of black sediment samples from the Berre lagoon (France) (Ranchou-Peyruse et al., 2006). Surprisingly, most of clones were closely related to aerobic anoxygenic phototrophic bacteria related to the Roseobacter clade whereas only two Roseobacter strains were isolated. The culture-dependent approach performed in parallel revealed the dominance of anaerobic purple sufur bacteria in these samples. The coexistence of both aerobic and anaerobic anoxygenic phototrophic bacteria has also been demonstrated in sediments from Antarctic and saline lakes (Karr et al., 2003, Thiel et al., 2010).

\section{Pigment diversity and reflectance measurements}

\subsection{Pigment diversity of microbial mats}

The microenvironment within a mat is characterized by physical-chemical gradients (e.g. light, $\mathrm{pH}$, nutrients), leading to high variability in the distribution of phototrophic microorganisms, both vertically within the top $\mathrm{mm}$ of the sediment (taxonomic stratification) and horizontally (high patchiness). Frequently, there is also significant temporal variability on biofilms that colonize intertidal areas as a result of the large physicochemical variations caused by the tide. The high variability exhibited by biofilms in such small scales cause significant sampling problems, e.g. to fully capture biofilm variability, many samples have to 
be taken, often more than it is logistically possible. Also, until recently, most of the available techniques for assessing microorganisms abundance or pigment diversity in biofilms were destructive (e.g. pigment extraction with organic solvents and quantification by HPLC). The destruction of the biofilm removes the existing physical-chemical gradients, changing significantly the environmental conditions of the biofilm under investigation. Thus, there is growing interest in developing remote sensing techniques that allow the non-destructive and non-invasive study of phototrophic microbial biofilms. Such techniques include: spectral reflectance, $\mathrm{O}_{2}$ micro-electrodes, optodes, Pulse-Amplitude-Modulation (PAM) fluorometry, Fast Repetition Rate Fluorometry (FRRF) fluorometry and Infra Red $\mathrm{CO}_{2}$ Gas Analyzer (IRGA) benthic chambers (e.g. Kühl, 2005, Kuhl and Polerecky, 2008, Migné et al., 2002, Stephens et al., 2003, Thar et al., 2001, V opel and Hawes, 2006, Wiggli et al., 1999). All these techniques allow the repetition of measurements in the same biofilm area and some can be used to infer about biofilm biomass or taxonomic composition. In this section we focused on the use of spectral reflectance in the study of photosynthetic microbial mats.

Microbial biofilm taxonomic diversity is reflected in the presence of different pigments. Some of these pigments can be used as "signatures" of the presence of specific groups in the biofilm, e.g. diatom dominated biofilms will show the abundant presence of fucoxanthin and chlorophyll $c$; cyanobacteria dominated biofilms will show a variety of cyanobacterial specific pigments (e.g. mixoxanthophyll, equinenone, etc.); and an anoxygenic bacterial biofilm will mainly show bacteriochlorophylls and carotenoids (Table 1). If for diatom and cyanobacterial biofilms numerous studies exist showing their pigment composition (e.g. Andréfouët et al., 2003, B rotas and Plante-Cuny, 2003, S tephens et al., 2003), only few papers focus on anoxygenic bacterial biofilms (e.g. Masse et al., 2002). Spectral reflectance can be used to identify and quantify the presence of different pigments in the biofilms, but it is first necessary to determine the spectral signatures of these pigments. It is thus useful to have good "ground truth" studies, i.e. spectral measurements taken together with measurements of the pigments present in the biofilm. Currently there are few studies that have attempted to establish the pigment spectral signatures of anoxygenic phototrophic biofilms. Although they are not consensual about which wavelengths should be used to detect bacteriochlorophyll, there are $3 \mathrm{~m}$ ain absorbance peaks attributed to bacteriochlorophyll $a$ : around $800 \mathrm{~nm}$, around $850 \mathrm{~nm}$ and around $870 \mathrm{~nm}$. The exact wavelengths depend on the type of bacteria present (Table 1). 


\subsection{Spectral reflectance of microbial phototrophic mats}

Spectral reflectance measurements have been used often in the estimation of biofilm microalgal biomass, using chlorophyll $a$ as a biomass proxy (e.g. Carrère et al., 2004). Chlorophyll $a$ strongly absorbs red light and reflects most of the infrared light. Using this information, a wide variety of chlorophyll $a$ based reflectance studies were developed, e.g. Normalized Difference Vegetation Index (NDVI), modified soil-adjusted vegetation index (MSAVI). To our knowledge no similar index exists to estimate anoxygenic phototrophic biofilms; although bacteriochlorophyll $a$ is frequently used to infer about the presence of anoxygenic phototrophic bacteria (e.g. Gitelson et al., 1999, Kühl and Jørgensen, 1992, Stal et al., 1984, Steenbergen and Korthals, 1982), it is not common to use the pigment content to quantify anoxygenic phototrophic bacterial biomass. Bacteriochlorophyll $a$ dominated biofilms typically show absorption features in the infrared region, whereas chlorophyll $a$ dominated biofilms do not (e.g. Stal et al., 1984). In the Roscoff Aber Bay where anoxygenic photosynthetic biofilms seasonally developed at the sediment surface, reflectance spectra recorded from different sediment areas allowed the determination of bacteriochlorophyll absorption features in the infrared region, with absorption maxima at 792 and $850 \mathrm{~nm}$ (Fig. 2). A spectral reflectance index is currently being developed by the authors to estimate bacteriochlorophyll content of this biofilm using bacteriochlorophyll absorption features.

Spectral reflectance has also been widely used with benthic phototrophic biofilms to follow diatom vertical migration within the sediment matrix (e.g. Serôdio et al., 2009), to follow photo-regulatory vertical movements (e.g. Perkins et al., 2010), to follow photo-physiological mechanisms (Jesus et al., 2008), and to a lesser extent to identify the presence of different taxonomic groups, e.g. microalgae, cyanobacteria, green and purple bacteria (e.g. Bachar et al., 2008, Prášil et al., 2009, Wiggli et al., 1999). Presently, most of the research done with spectral reflectance on anoxygenic biofilms seems to have been focused on the identification of the presence of different taxonomic groups in the biofilm. With the introduction of hyperspectral (HS) imaging technology it became possible to map sediment biofilms with high spectral and spatial resolution (e.g. Bachar et al., 2008). HS imaging is a very sensitive and minimally invasive tool that can be used in the investigation of biofilm spatial organization role in mat ecosystem functions, providing the possibility of imaging microbial identity and activity at high spatio-temporal resolution. Presently, the majority of the work involving HS imaging seems to address mainly questions relating spatial distribution of the different taxonomic groups that colonize the sediment, vertically and horizontally (Kuhl and Polerecky, 
2008, Polerecky et al., 2009). However, some research has started to emerge using combinations of imaging techniques to infer about the relationships between the different microalgal groups and their environment. For instance, Bachar et al. (2008) used hyperspectral imaging of reflectance spectra $\left(4^{\text {th }}\right.$ derivative of spectral images with 460 $913 \mathrm{~nm}$ spectral resolution at $30 \times 30 \mu \mathrm{m}$ spatial resolution) and of emission spectra to map the distribution of different pigments (chlorophyll $a$, phycocyanin, bacteriochlorophyll $a$ and bacteriochlorophyll $c$ ). Both spectral methods were sensitive enough to detect biofilm stratification within the sediment, showing the spectral signatures of chlorophyll $a$ and zeaxanthin closer to the sediment surface, a mid layer 3-4 $\mathrm{mm}$ of bacteriochlorophyll $c$ and bacteriochlorophyll $a$ at deeper layers $(5.5-7 \mathrm{~mm})$. Using HS imagery these authors rejected their original hypothesis that Chloroflexaceae would be closely associated with the distribution of oxygenic phototrophs and proposed an alternative hypothesis that Chloroflexaceae is maximal in locations where both photosynthate excretion and sulfate reduction occur during a light / dark cycle.

In conclusion, although considerable research on microalgae phototrophic biofilms using spectral reflectance tools already exists, there is a gap in current knowledge regarding the use of these techniques for quantification and study of anoxygenic phototrophs.

\section{Role of microbial mats in the functioning of coastal ecosystems}

\subsection{Role of microbial mats in sediment stability}

Although the cohesive strength of one sediment may depend on its physicochemical properties, such as water content, density, mineralogy, plasticity, salinity and $\mathrm{pH}$ (Dade et al., 1992), its stability may correlate better with biological parameter than with nonbiological ones (Paterson et al., 2000). Microbial exopolymeric secretions are increasingly recognized as a major stabilising factor (Stal, 2010). Extracellular Polymeric Substances (EPS) are a ubiquitous component of marine ecosystems primarily composed of carbohydrates, proteins and lesser amounts of other components. They have multiple roles in aquatic systems: attachment to substrata, flotation and locomotion, feeding, protection against desiccation / UV / pollution, development of biofilms, communication (Decho, 1990). These molecules, mostly produced by diatoms and bacteria, compose a highly hydrated matrix more or less associated with cells. Tightly-wound capsules are secreted during exponential growth phase and 
allegedly serve protective effects to the cell, whereas loose slimes allow microorganisms to attach each other and to sediment (Decho, 1990). The high amounts of EPS present in the sediment glue the grains together, thus enhancing the resistance of sediment to erosion and making it more stable (Paterson et al., 2000, Stal, 2010). If the resistance to erosion generally correlates well with carbohydrate and protein concentrations, variations in EPS quality influence as well sediment stability (Sutherland et al., 1998, van Duyl et al., 2000). Moreover, cyanobacterial filaments trap sediment particles and reinforce cohesion (Stal, 2010). Figure 3 summarised the potential influence of microbial mats on sediment stability. Given the importance of sediment stability in coastal ecosystems (which are typically constrained by strong physical and geochemical gradients), microorganisms are increasingly recognized as ecosystem engineers.

In the future, more studies are required in order to understand how EPS composition and diversity modify sediment properties. Particularly, little is known about stabilisation in mats of anoxygenic phototrophic bacteria. Yet abundance of purple sulphur bacteria may correlate with erosion threshold of sediment, and these bacteria appear to produce far more EPS than diatoms (Grant and Gust, 1987). Thus the erosion of sediment is lower when purple phototrophic mats are present (Van Gemerden et al., 1989a). Recent measurements of sediment adhesion in Roscoff Aber Bay showed that sediment cohesion was enhanced and that sediment was stabilised by purple phototrophic bacteria, particularly under high bacterial abundance (Fig 4). Further investigations are now required to link stabilisation with the quantity or quality of the EPS produced by purple sulphur bacteria.

4.2. Production and respiration of microbial mats organic matter and its fate into the coastal food web

Microbial mats are very productive ecosystems (e.g. about $200 \mathrm{gC} \cdot \mathrm{m}^{-2} \cdot \mathrm{y}^{-1}$ in the Ebro Delta, Urmeneta et al., 1998). The Winkler titration method (Winkler, 1888), the incorporation of ${ }^{14} \mathrm{C}$ labeled bicarbonate, the fast-responding $\mathrm{CO}_{2}$ microelectrodes (de Beer et al., 1997) or the measurements of total DIC fluxes (e.g. Wieland et al., 2005) have been used extensively to measure primary production, but most of the estimates in benthic photosynthetic mats were performed to date with oxygen microelectrodes (Oren, 2009), by measuring rates of oxygen depletion at different depths during light-dark shifts (Revsbech and Jørgensen, 1983). This method allows accurate estimation of gross primary production rates across the mat-water 
interface from the profiles providing that irradiance, temperature as well as porosity of the substrates are known (Wieland and Kühl, 2000). Oxygen measurements can provide information about both gross primary production and respiration of the microbial mats at millimetre scale. They revealed that microorganisms thrive in such a closeness that they mutually influence each other (Van Gemerden, 1993). Biological processes usually metabolically incompatible are found to occur simultaneously within the mats, which imply a tight coupling between them. The different members of the community are thus mutually dependent so that the entire ecosystem is often considered as self-sustaining (Des Marais, 2003). The development of electrochemical and optical microprobes has attracted many microbiologists during the past decades probably because their resolution is particularly suitable for the study of microbial environments. But, ironically, whilst we have to date a good understanding of the chemical and physical conditions that microorganisms experience at millimeter scales in microbial mats, we still do not know precisely which role microbes play in biogeochemical cycles at larger scales.

In addition, microbial mats can represent a significant source of fixed carbon and nitrogen to the surroundings and they may serve as an important food source to higher trophic levels (Joye and Lee, 2004). Recently, it has been shown that anoxygenic microbial mats may support the diet of inhabiting mud snails (Riera, 2010). In addition, microbial mats of the intertidal area which are dominated by diatoms generally serve as a food source for many invertebrates of the macrofauna and meiofauna (e.g.Hagerthey et al., 2002, Riera and Hubas, 2003), including many commercial species such as penaeid shrimp postlarvae (Al-Maslamani et al., 2009) or the oyster Crassostrea gigas (Riera and Richard, 1996). But despite the marked role they play into the coastal food web, the fate of microbial mats organic matter has seldom been addressed. Bacterial production has been proved to be a significant food source to benthic grazers and a sink of organic carbon in the food web of intertidal sediments (van Oevelen et al., 2006) but further studies are still needed particularly concerning anoxygenic microbial mats.

Indeed, mass bloom of anoxygenic phototrophic bacteria can develop at the sediment surface if the organic matter input is strong enough (Herbert and Welsh, 1994) forming purple microbial mats which are characterised by the absence of oxygenic photosynthesis. The accumulation of organic matter at the sediment surface stimulates respiration and, below 2 to $3 \mathrm{~mm}$ depth, sediment becomes totally anoxic and characterised by very high sulfate-reducing rates (Bolam et al., 2000, Nedergaad et al., 2002), allowing the exclusive growth of anoxygenic purple bacteria. Primary production and respiration rates measurements are still 
scarce on these types of mats. Recently, the high contribution of Chloroflexus-like anoxygenic phototrophs (green non-sulphur bacteria) to the gross primary production and community respiration of a microbial mat was found to be strongly dependent upon the light availability in the near infrared region (Polerecky et al., 2007). This highlights the fact that understanding the contribution of anoxygenic phototrophs to total primary production and respiration is more complex than previously thought and that more studies on anoxygenic microbial mats are required.

Microbial mats are a remarkable example of the various forms of respiration that co-exist in aquatic habitats. Anaerobic respiration as well as aerobic respiration and re-oxydation processes have been relatively well studied in these systems. From the surface to the depth, the redox potential decreases, which influence the distribution of the different respiration pathways. Along the sediment depth, the chemical reactions involve different terminal electron acceptors and display apparent free energy yields which decrease with increasing depth (Hoehler, 2004). Carbon fluxes across the mat-water interface are generally deduced from oxygen measurements by applying known respiratory quotients (RQ). However, most of the RQ apply to conventional aerobic respiration and have no useful meaning in case total respiration mainly occurs via anaerobic pathways (Williams and Del Giorgio, 2005). Total DIC fluxes in benthic chamber enclosures or chambers equipped with a $\mathrm{CO}_{2}$ infra-red gas analysers (Migné et al., 2002) are an efficient way to measure $\mathrm{C}$ fluxes across the mat-water or mat-air interface. They have been used extensively on emersed diatom biofilms to estimate their annual carbon budgets (Hubas and Davoult, 2006, Migné et al., 2004, S pilmont et al., 2006) but rarely on other microbial mats to our knowledge.

\section{Conclusions and future directions}

The current knowledge of ecology, ecophysiology and role of anoxygenic purple microbial mats is far less documented than those dominated by cyanobacteria and / or diatoms. Molecular approaches have provided fresh insight into the diversity of microbial mats but the role of microbial species diversity in sustaining ecosystem processes like primary production has seldom been addressed (but see Forster et al., 2006). As revealed by spectral reflectance measurements, the distribution of phototrophic microorganisms in coastal ecosystems is highly variable. Remote sensing methods are probably an efficient way to perform a real integration of these systems at larger scales. Indeed, coastal habitats are amongst the most 
productive ecosystems on earth and the contribution of anoxygenic bacteria to the coastal $\mathrm{C}$ and $\mathrm{N}$ cycles and their role in sustaining local food webs are probably underestimated.

Techniques such as HS imaging combined with state of the art optical sensors (e.g. optodes, Imaging PAM) will surely help to elucidate the distribution, trophic, geochemical roles of anoxygenic phototrophic biofilms as well as investigate in depth their photobiology in intact samples. In addition, new generations of ion microprobes based on $\mathrm{m}$ ass spectrometry of secondary ions (SIMS) are now available and particularly appropriate to the study of microbial mats. They allow the analysis of any isotopic composition of a given sample surface and the distribution of labelled molecules (e.g. $\mathrm{H}^{13} \mathrm{CO}_{3}{ }^{-}$) at a sub-cellular scales. It is thus now possible to determine the rate of carbon and nitrogen fixation at the cellular level (Musat et al., 2008) which would give valuable information about the functioning of the microbial mats in the future.

Acknowledgement: We would like to thank three anonymous reviewers for their constructive remarks as well as Nicolas Spilmont and Dominique Davoult for their help with field work. This work is a contribution to the French national CNRS program EC2CO-MicroBien (Microbiologie Environnementale). Thanks are due to Ecole Normale Supérieure (ENS) Paris for supporting Claire Passarelli PhD grant. Bruno Jesus was funded by a FCT postdoctoral grant (POCI/BPD/20993/2004), the project SEAPhoB (PDTC/MAR/101410/2008) and the program ASSEMBLE ( $\left.{ }^{\circ} 227799\right)$.

\section{References}

Achenbach, L. A., Carey, J., Madigan, M. T., 2001. Photosynthetic and phylogenetic primers for detection of anoxygenic phototrophs in natural environments. Applied and Environmental Microbiology.67,2922-2926.

Al-Maslamani, I., Le Vay, L., Kennedy, H., 2009. Feeding on intertidal microbial mats by postlarval tiger shrimp, Penaeus semisulcatus De Haan. Marine Biology.156,20012009.

Andréfouët, S., Payri, C., Hochberg, E. J., Che, L. M., Atkinson, M. J., 2003. Airborne hyperspectral detection of microbial mat pigmentation in Rangiroa atoll (French Polynesia). Limnology and Oceanography.48,426-430.

Bachar, A., Polerecky, L., Fischer, J. P., Vamvakopoulos, K., de Beer, D., Jonkers, H. M., 2008. Two-dimensional mapping of photopigment distribution and activity of Chloroflexus-like bacteria in a hypersaline microbial mat. Fems Microbiology Ecology.65,434-448.

Bolam, S. G., Fernandes, T. F., Read, P., Raffaelli, D., 2000. Effects of macroalgal mats on intertidal sandflats: an experimental study. Journal of Experimental Marine Biology and Ecology.249,123-137. 
Brotas, V., Plante-Cuny, M. R., 2003. T he use of HPLC pigment analysis to study microphytobenthos communities. Acta Oecologica-International Journal of Ecology.24,S109-S115.

Canfield, D. E., Des Marais, D. J., 1993. Biogeochemical Cycles of Carbon, Sulfur, and Free Oxygen in a Microbial Mat. Geochimica Et Cosmochimica Acta.57,3971-3984.

Carrère, V., Spilmont, N., Davoult, D., 2004. Comparison of simple techniques for estimating chlorophyll $a$ concentration in the intertidal zone using high spectral-resolution fieldspectrometer data. Marine Ecology-Progress Series.274,31-40.

Caumette, P., 1986. Phototrophic sulfur bacteria and sulfate-reducing bacteria causing red waters in a hallow brackish coastal lagoon (Prévost lagoon, France). Fems Microbiology Ecology.38,113-124.

Caumette, P., Baleux, B., 1980. Étude des eaux rouges dues à la prolifération des bactéries photosynthétiques sulfo-oxydantes dans l'étang du $\mathrm{P}$ révost, lagune saumâtre méditerranéenne. Marine Biology.56,183-194.

Caumette, P., Baulaigue, R., Matheron, R., 1988. Characterization of Chromatium salexigens sp. nov., a halophilic Chromatiaceae isolated from Mediterranean salinas. Systematic and Applied Microbiology.10,284-292.

Caumette, P., Baulaigue, R., Matheron, R., 1991. Thiocapsa halophila sp. nov., a new halophilic phototrophic purple sulfur bacterium Archives of Microbiology.155,170176.

Caumette, P., Imhoff, J. F., Suling, J., Matheron, R., 1997. Chromatium glycolicum sp nov, a moderately halophilic purple sulfur bacterium that uses glycolate as substrate. Archives of Microbiology.167,11-18.

Caumette, P., Matheron, R., Raymond, N., Relexans, J. C., 1994. M icrobial mats in the hypersaline ponds of Mediterranean salterns (Salin-de-Giraud, France). Fems Microbiology Ecology.13,273-286.

Dade, W. B., Nowell, A. R. M., Jumars, P. A., 1992. Predicting erosion resistance of muds. Marine Geology.105,285-297.

de Beer, D., Glud, A., Epping, E., Kuhl, M., 1997. A fast-responding CO2 microelectrode for profiling sediments, microbial mats, and biofilms. Limnology and Oceanography.42,1590-1600.

de Wit, R., van Gemerden, H., $1987 \mathrm{C}$ hemolithotrophic growth of the phototrophic sulfur bacterium Thiocapsa roseopersicina. FEMS Microbiology Ecology.45,117-126

de Wit, R., van Gemerden, H., 1990. Growth of the phototrophic purple sulfur bacterium Thiocapsa roseopersicina under oxic/anoxic regimens in the light. FEMS Microbiology Ecology 73,69-76.

Decho, A. W., 1990. Microbial exopolymer secretions in ocean environments: their role(s) in food webs and marine processes. Oceanography and Marine Biology: an Annual Review.28,73-153.

Des Marais, D. J., 2003. Biogeochemistry of hypersaline microbial mats illustrates the dynamics of modern microbial ecosystems and the early evolution of the biosphere. Biological Bulletin.204,160-167.

Forster, R. M., Creach, V., Sabbe, K., Vyverman, W., Stal, L. J., 2006. B iodiversityecosystem function relationship in microphytobenthic diatoms of the Westerschelde estuary. Marine Ecology-Progress Series.311,191-201.

Fourçans, A., de Oteyza, T. G., Wieland, A., Sole, A., Diestra, E., van Bleijswijk, J., Grimalt, J. O., Kuhl, M., et al., 2004. C haracterization of functional bacterial groups in a hypersaline microbial mat community (Salins-de-Giraud, Camargue, France). Fems Microbiology Ecology.51,55-70. 
Fourçans, A., Sole, A., Diestra, E., Ranchou-Peyruse, A., Esteve, I., Caumette, P., Duran, R., 2006. Vertical migration of phototrophic bacterial populations in a hypersaline microbial mat from Salins-de-Giraud (Camargue, France). Fems Microbiology Ecology.57,367-377.

Franks, J., Stolz, J. F., 2009. F lat laminated microbial mat communities. Earth-Science Reviews.96,163-172.

Giani, D., Seeler, J., Giani, L., Krumbein, W. E., 1989. Microbial mats and physicochemistry in a saltern in the Brittany (France) and in a laboratory scale saltern model. Fems Microbiology Ecology.62,151-162.

Gitelson, A., Stark, R., Dor, I., Michelson, O., Yacobi, Y. Z., 1999. Optical characteristics of the phototroph Thiocapsa roseoparsicina and implications for real-time monitoring of the bacteriochlorophyll concentration. Applied and Environmental Microbiology.65,3392-3397.

Grant, J., Gust, G., 1987. Prediction of coastal sediment stability from photopigment content of mats of purple sulfur bacteria. Nature.330,244-246.

Guyoneaud, R., Matheron, R., Baulaigue, R., Podeur, K., Hirschler, A., Caumette, P., 1996. Anoxygenic phototrophic bacteria in eutrophic coastal lagoons of the French Mediterranean and Atlantic coasts (Prevost Lagoon, Arcachon Bay, Certes fishponds). Hydrobiologia.329,33-43.

Hagerthey, S. E., Defew, E. C., Paterson, D. M., 2002. Influence of Corophium volutator and Hydrobia ulvae on intertidal benthic diatom assemblages under different nutrients and temperature regimes. Marine Ecology Progress Series.245,47-59.

Herbert, R., Welsh, D. T., 1994. Establishment of phototrophic purple sulphur bacteria in microbial mat systems, in: L. J. Stal and P. Caumette (eds), Microbial mats: Structure, Development and Environmental Significance, Heidelberg: Springer - Verlag, pp. 5160.

Herbert, R. A., 1985. Development of mass blooms of photosynthetic bacteria on sheltered beaches in Scapa Flow, Orkney Islands. Proceedings of the Royal Society of Edinburgh Section B-Biological Sciences.87,15-25.

Hiraishi, A., Ueda, Y., 1995. Isolation and characterization of Rhodovulum strictum sp. nov. and some other purple nonsulfur bacteria from colored blooms in tidal and seawater pools. International Journal of Systematic Bacteriology.45,882-882.

Hoehler, T. M., 2004. Biological energy requirements as quantitative boundary conditions for life in the subsurface. Geobiology.2,205-215.

Hubas, C., Davoult, D., 2006. D oes seasonal proliferation of Enteromorpha sp. affect the annual benthic metabolism of a small macrotidal estuary? (Roscoff Aber Bay, France). Estuarine Coastal and Shelf Science.70,287-296.

Imhoff, J. F., 2001. True marine and halophilic anoxygenic phototrophic bacteria. Archives of Microbiology.176,243-254.

Jesus, B., Mouget, J. L., Perkins, R. G., 2008. Detection of diatom xanthophyll cycle using spectral reflectance. Journal of Phycology.44,1349-1359.

Jorgensen, B. B., 1977. Distribution of colorless sulfur bacteria (Beggiatoa spp.) in a coastal marine sediment Marine Biology.41,19-28.

Joye, S. B., Lee, R. Y., 2004. Benthic microbial mats: Important sources of fixed Nitrogen ans Carbon to the Twin Cays, Belize ecosystem. Atoll Research Bulletin.528,1-24.

Karr, E. A., Sattley, W. M., Jung, D. O., Madigan, M. T., Achenbach, L. A., 2003. Remarkable diversity of phototrophic purple bacteria in a permanently frozen Antarctic lake. Applied and Environmental Microbiology.69,4910-4914.

Kühl, M., 2005. O ptical microsensors for analysis of microbial communities, in, Environmental Microbiology, pp. 166-199. 
Kühl, M., Jørgensen, B. B., 1992. Spectral light measurements in microbenthic phototrophic communities with a fiber-optic microprobe coupled to a sensitive diode array detector Limnology and Oceanography.37,1813-1823.

Kuhl, M., Polerecky, L., 2008. Functional and structural imaging of phototrophic microbial communities and symbioses. Aquatic Microbial Ecology.53,99-118.

Larson, F., Lubarsky, H. V., Gerbersdorf, S. U., Paterson, D. M., 2009. Surface adhesion measurements in aquatic biofilms using magnetic particle induction: MagPI. Limnology and Oceanography-Methods.7,490-497.

Ley, R. E., Harris, J. K., Wilcox, J., Spear, J. R., Miller, S. R., Bebout, B. M., Maresca, J. A., Bryant, D. A., et al., 2006. Unexpected diversity and complexity of the Guerrero Negro hypersaline microbial mat. Applied and Environmental Microbiology.72,36853695 .

Martinez-Alonso, M., Van Bleijswijk, J., Gaju, N., Muyzer, G., 2005. Diversity of anoxygenic phototrophic sulfur bacteria in the microbial mats of the Ebro Delta: a combined morphological and molecular approach. Fems Microbiology Ecology.52,339-350.

Masse, A., Pringault, O., de Wit, R., 2002. Experimental study of interactions between purple and green sulfur bacteria in sandy sediments exposed to illumination deprived of nearinfrared wavelengths. Applied and Environmental Microbiology.68,2972-2981.

Migné, A., Davoult, D., Spilmont, N., Menu, D., Boucher, G., Gattuso, J. P., Rybarczyk, H., 2002. A closed-chamber CO2-flux method for estimating intertidal primary production and respiration under emersed conditions. Marine Biology.140,865-869.

Migné, A., Spilmont, N., Davoult, D., 2004. In situ measurements of benthic primary production during emersion: seasonal variations and annual production in the Bay of Somme (eastern English Channel, France). Continental Shelf Research.24,1437-1449.

Mir, J., Martinezalonso, M., Esteve, I., Guerrero, R., 1991. Vertical stratification and microbial assemblage of a microbial mat in the Ebro Delta (Spain). Fems Microbiology Ecology.86,59-68.

Mouné, S., Caumette, P., Matheron, R., Willison, J. C., 2003. Molecular sequence analysis of prokaryotic diversity in the anoxic sediments underlying cyanobacterial mats of two hypersaline ponds in Mediterranean salterns. Fems Microbiology Ecology.44,117-130.

Musat, N., Halm, H., Winterholler, B., Hoppe, P., Peduzzi, S., Hillion, F., Horreard, F., Amann, R., et al., 2008. A single-cell view on the ecophysiology of anaerobic phototrophic bacteria. Proceedings of the National Academy of Sciences of the United States of America. 105,17861-17866.

Navarrete, A., Peacock, A., Macnaughton, S. J., Urmeneta, J., Mas-Castella, J., White, D. C., Guerrero, R., 2000. P hysiological status and community composition of microbial mats of the Ebro Delta, Spain, by signature lipid biomarkers. Microbial Ecology.39,92-99.

Nedergaad, R. I., Risgaard-Petersen, N., Finster, K., 2002. T he importance of sulfate reduction associated with Ulva lactuca thalli during decomposition: a mesocosm experiment. Journal of Experimental Marine Biology and Ecology.275,15-29.

Nicholson, J. A. M., Stolz, J. F., Pierson, B. K., 1987. Structure of a microbial mat at Great Sippewissett Marsh, Cape Cod, Massachussets. Fems Microbiology Ecology.45,343364.

Oren, A., 2009. Saltern evaporation ponds as model systems for the study of primary production processes under hypersaline conditions. Aquatic Microbial Ecology.56,193-204.

Overmann, J., Garcia-Pichel, F., 2006. The Phototrophic Way of Life, in: M. Dworkin, S. Falkow, E. Rosenberg and K.-H. Schleifer (eds), The prokaryotes, A Handbook on the 
Biology of bacteria: Ecophysiology and Biochemistry, Heidelberg: Springer, pp. 32 85.

Paerl, H. W., Pinckney, J. L., 1996. A mini-review of microbial consortia: Their roles in aquatic production and biogeochemical cycling. Microbial Ecology.31,225-247.

Paterson, D. M., 1997. B iological mediation of sediment erodibility: ecology and physical dynamics, in: N. Burt, R. Parker and J. Watts (eds), Cohesive Sediments: John Wiley and Sons, pp. 215-229.

Paterson, D. M., Tolhurst, T. J., Kelly, J. A., Honeywill, C., de Deckere, E. M. G. T., Huet, V., Shayler, S. A., Black, K. S., et al., 2000. Variations in sediment properties, Skeffling mudflat, Humber Estuary, UK. Continental Shelf Research.20,1373-1396.

Paterson, D. M., Wiltshire, K. H., Miles, A., Blackburn, J., Davidson, I., Yates, M. G., McGrorty, S., Eastwood, J. A., 1998. M icrobiological mediation of spectral reflectance from intertidal cohesive sediments. Limnology and Oceanography.43,1207-1221.

Perkins, R. G., Lavaud, J., Serôdio, J., Mouget, J. L., Cartaxana, P., Rosa, P., Barillé, L., Brotas, V., et al., 2010. Vertical cell movement is a primary response of intertidal benthic biofilms to increasing light dose. Marine Ecology Progress Series.416,93-103.

Polerecky, L., Bachar, A., Schoon, R., Grinstein, M., Jørgensen, B. B., de Beer, D., Jonkers, H. M., 2007. C ontribution of Chloroflexus respiration to oxygen cycling in a hypersaline microbial mat from Lake Chiprana, Spain. Environmental Microbiology.9,2007-2024.

Polerecky, L., Bissett, A., Al-Najjar, M., Faerber, P., Osmers, H., Suci, P. A., Stoodley, P., de Beer, D., 2009. Modular Spectral Imaging System for Discrimination of Pigments in Cells and Microbial Communities. Applied and Environmental Microbiology.75,758771.

Prášil, O., Bina, D., Medová, H., Reháková, K., Zapomelová, E., Veselá, J., Oren, A., 2009. Emission spectroscopy and kinetic fluorometry studies of phototrophic microbial communities along a salinity gradient in solar saltern evaporation ponds of Eilat, Israel. Aquatic Microbial Ecology.56,285-296.

Ranchou-Peyruse, A., Herbert, R., Caumette, P., Guyoneaud, R., 2006. C omparison of cultivation-dependent and molecular methods for studying the diversity of anoxygenic purple phototrophs in sediments of an eutrophic brackish lagoon. Environmental Microbiology.8,1590-1599.

Revsbech, N. P., Jørgensen, B. B., 1983. Photosynthesis of Benthic Microflora Measured with High Spatial-Resolution by the Oxygen Microprofile Method - Capabilities and Limitations of the Method. Limnology and Oceanography.28,749-756.

Riera, P., 2010. Trophic plasticity of the gastropod Hydrobia ulvae within an intertidal bay (Roscoff, France): A stable isotope evidence. Journal of Sea Research.63,78-83.

Riera, P., Hubas, C., 2003. Trophic ecology of nematodes from various microhabitats of the Roscoff Aber Bay (France) : importance of stranded macroalgae evidenced through ä13C and ä15N. Marine Ecology Progress Series.260,151-159.

Riera, P., Richard, P., 1996. Isotopic determination od food sources of Crassostrea gigas along a trophic gradient in the estuarine bay of Marénnes-Oléron. Estuarine Coastal and Shelf Science.42,347-360.

Rothermich, M. M., Guerrero, R., Lenz, R. W., Goodwin, S., 2000. Characterization, seasonal occurrence, and diel fluctuation of poly(hydroxyalkanoate) in photosynthetic microbial mats. Applied and Environmental Microbiology.66,4279-4291.

Serôdio, J., Cartaxana, P., Coelho, H., Vieira, S., 2009. Effects of chlorophyll fluorescence on the estimation of microphytobenthos biomass using spectral reflectance indices. Remote Sensing of Environment.113,1760-1768. 
Spilmont, N., Davoult, D., Migné, A., 2006. Benthic primary production during emersion: in situ measurements and potential primary production in the Seine Estuary ( English Channel , France ). Marine Pollution Bulletin.53,49-55.

Stal, L. J., 2010. Microphytobenthos as a biogeomorphological force in intertidal sediment stabilization. Ecological Engineering.36,236-245.

Stal, L. J., Caumette, P., 1994. Microbial mats: Structure and Environmental Significance, Springer-Verlag, Heidelberg.

Stal, L. J., van Gemerden, H., Krumbein, W. E., 1985. Structure and development of a benthic marine microbial mat. Fems Microbiology Ecology.31,111-125.

Stal, L. J., Vangemerden, H., Krumbein, W. E., 1984. T he Simultaneous Assay of Chlorophyll and Bacteriochlorophyll in Natural Microbial Communities. Journal of Microbiological Methods.2,295-306.

Steenbergen, C. L. M., Korthals, H. J., 1982. Distribution of phototrophic microorganisms in the anaerobic and microaerophilic strata of Lake Vechten (The Netherlands). Pigment analysis and role in primary production. Limnology and Oceanography.27,883-895.

Stephens, F. C., Louchard, E. M., Reid, R. P., Maffione, R. A., 2003. Effects of microalgal communities on reflectance spectra of carbonate sediments in subtidal optically shallow marine environments. Limnology and Oceanography.48,535-546.

Sutherland, T. F., Grant, J., Amos, C. L., 1998. The effect of carbohydrate production by the diatom Nitzschia curvilineata on $\mathrm{t}$ he erodibility of sediment. Limnology and Oceanography.43,65-72.

Thar, R., Kühl, M., Holst, G., 2001. F iber-optic fluorometer for microscale mapping of photosynthetic pigments in microbial communities. Applied and Environmental Microbiology.67,2823-2828.

Thiel, V., Tank, M., Neulinger, S. C., Gehrman, L., Dorador, C., Imhoff, J. F., 2010. Unique communities of anoxygenic phototrophic bacteria in saline lakes of Salar de Atacama (Chile): evidence for a new phylogenetic lineage of phototrophic Gammaproteobacteria from pufLM gene analyses. Fems Microbiology Ecology.

Urmeneta, J., Alcoba, O., Razquin, E., Tarroja, E., Navarrete, A., Guerrero, R., 1998. Oxygenic photosynthesis and respiratory activity in microbial mats of the Ebro Delta, Spain, by oxygen exchange method. Current Microbiology.37,151-155.

van Duyl, F. C., de Winder, B., Kop, A. J., Wollenzien, U., 2000. Consequences of diatom mat erosion for carbohydrate concentrations and heterotrophic bacterial activities in intertidal sediments of the Ems-Dollard estuary. Continental Shelf Research.20,13351349.

Van Gemerden, H., 1993. Microbial mats - a joint venture. Marine Geology.113,3-25.

Van Gemerden, H., Dewit, R., Tughan, C. S., Herbert, R. A., 1989a. Development of mass blooms of Thiocapsa roseopersicina on sheltered beaches on the Orkney Islands. Fems Microbiology Ecology.62,111-118.

van Gemerden, H., Mas, J., 1995. Ecology of phototrophic sulfur bacteria, in: R. E. Blankenship, M. T. Madigan and C. E. Bauer (eds), Anoxygenic photosynthetic bacteria, Advances in photosynthesis, vol. 2: anoxygenic phototrophic bacteria, Dordrecht, The Netherlands: Kluwer Academic Publishers, pp. 49-85.

Van Gemerden, H., Tughan, C. S., Dewit, R., Herbert, R. A., 1989b. Laminated microbial ecosystems on sheltered beaches in Scapa Flow, Orkney Islands. Fems Microbiology Ecology.62,87-102.

van Oevelen, D., Middelburg, J. J., Soetaert, K., Moodley, L., 2006. The fate of bacterial carbon in an intertidal sediment: Modeling an in situ isotope tracer experiment. Limnology and Oceanography.51,1302-1314. 
Villanueva, L., Del Campo, J., Guerrero, R., 2010. Diversity and physiology of polyhydroxyalkanoate-producing and -degrading strains in microbial mats. Fems Microbiology Ecology.74,42-54.

Visscher, P. T., Beukema, J., van Gemerden, H., 1991. In situ characterization of sediments: Measurements of oxygen and sulfide profiles with a novel combined needle electrode. Limnology and Oceanography.36,1476-1480.

Vopel, K., Hawes, I., 2006. Photosynthetic performance of benthic microbial mats in Lake Hoare, Antarctica. Limnology and Oceanography.51,1801-1812.

Wieland, A., Kühl, M., 2000. Irradiance and temperature regulation of photosynthesis and O2 consuption in a hypersaline cyanobacterial mat (Solar Lake, Egypt). Marine Biology.137,71-85.

Wieland, A., Kuhl, M., McGowan, L., Fourcans, A., Duran, R., Caumette, P., de Oteyza, T. G., Grimalt, J. O., et al., 2003. M icrobial mats on the Orkney Islands revisited: Microenvironment and microbial community composition. Microbial Ecology.46,371390.

Wieland, A., Zopfi, J., Benthien, A., Kuhl, M., 2005. B iogeochemistry of an iron-rich hypersaline microbial mat (Camargue, France). Microbial Ecology.49,34-49.

Wiggli, M., Smallcombe, A., Bachofen, R., 1999. Reflectance spectroscopy and laser confocal microscopy as tools in an ecophysiological study of microbial mats in an alpine bog pond. Journal of Microbiological Methods.34,173-182.

Williams, P. J., Del Giorgio, P. A., 2005. Respiration in aquatic ecosystems: history and background, in: P. A. del Giorgio and P. J. Williams (eds), Respiration in aquatic ecosystems: Oxford University Press, pp. 1-17.

Winkler, L. W., 1888. Die Bestimmung des im Wasser gelösten Sauerstoffen. Berichte der Deutschen Chemischen Gesellschaft.21,2843-2855. 


\section{Figures}

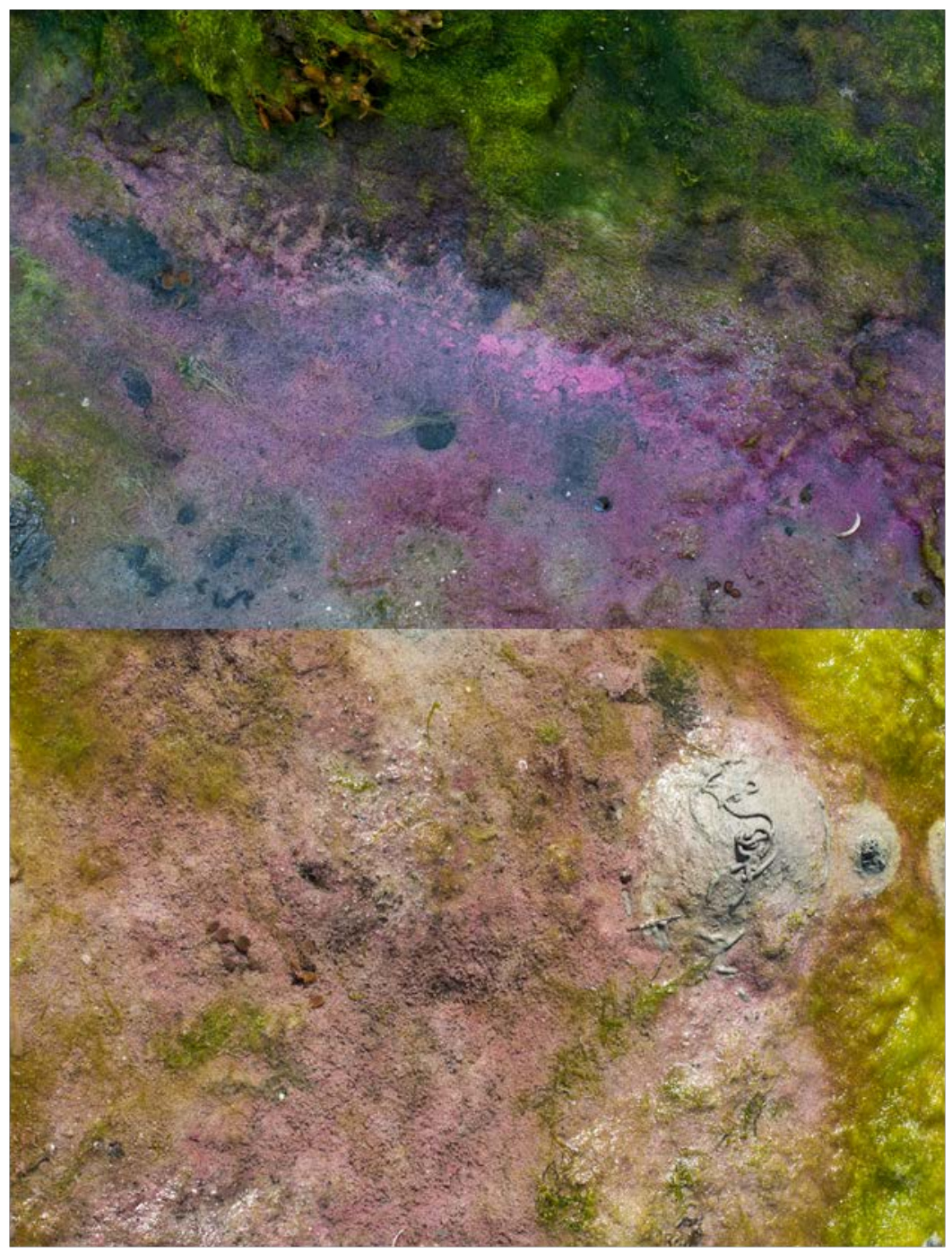

Figure 1: pictures of purple phototrophic mats, underwater (top panel) and emerged (bottom panel), in Roscoff Aber Bay. 

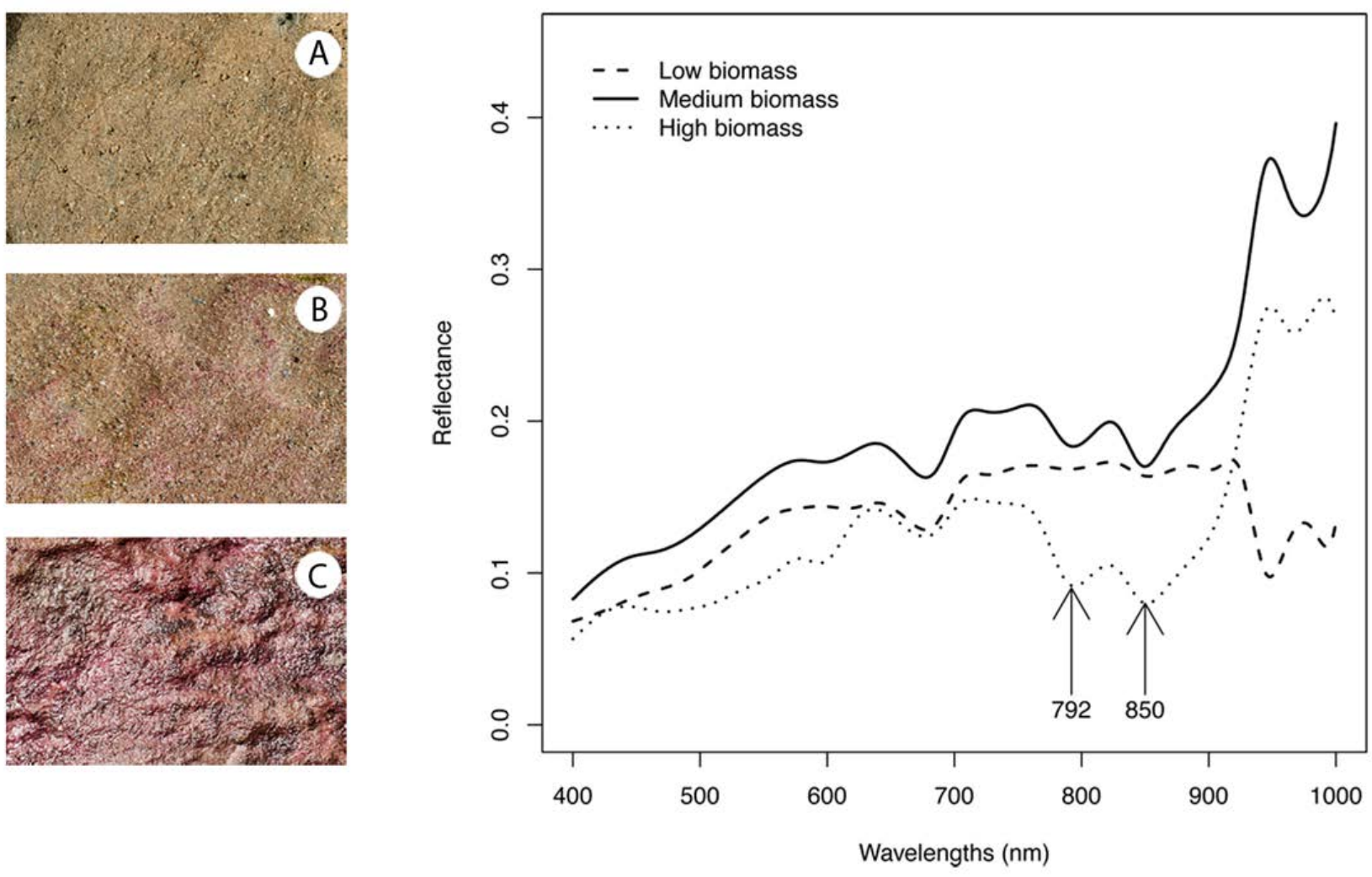

Figure 2: left panel: pictures of sites with low (A), medium (B) and high (C) biomass of purple sulfur bacteria, in Roscoff Aber Bay. Right panel : spectral reflectance of the sediment, in sites with low (dashed line), medium (solid line) and high (dotted line) biomass of these bacteria. The arrows point the bacteriochlorophyll $a$ absorption peaks. 


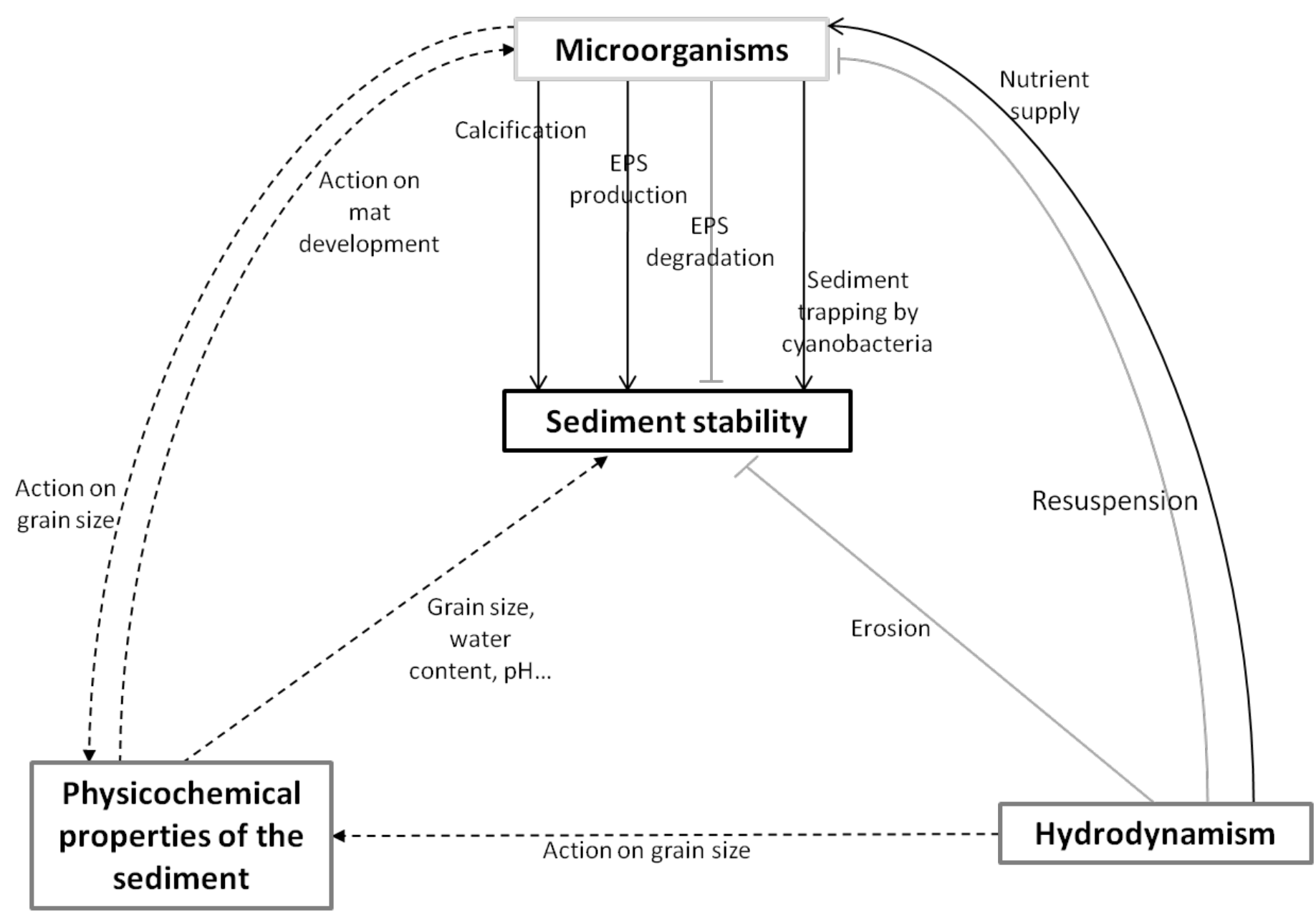

Abiotic parameters

Figure 3: biotic and abiotic parameters influencing sediment stability. Arrow with black solid line: stimulates. Arrow with gray solid line: inhibits. Arrow with dashed line: has an influence on. 


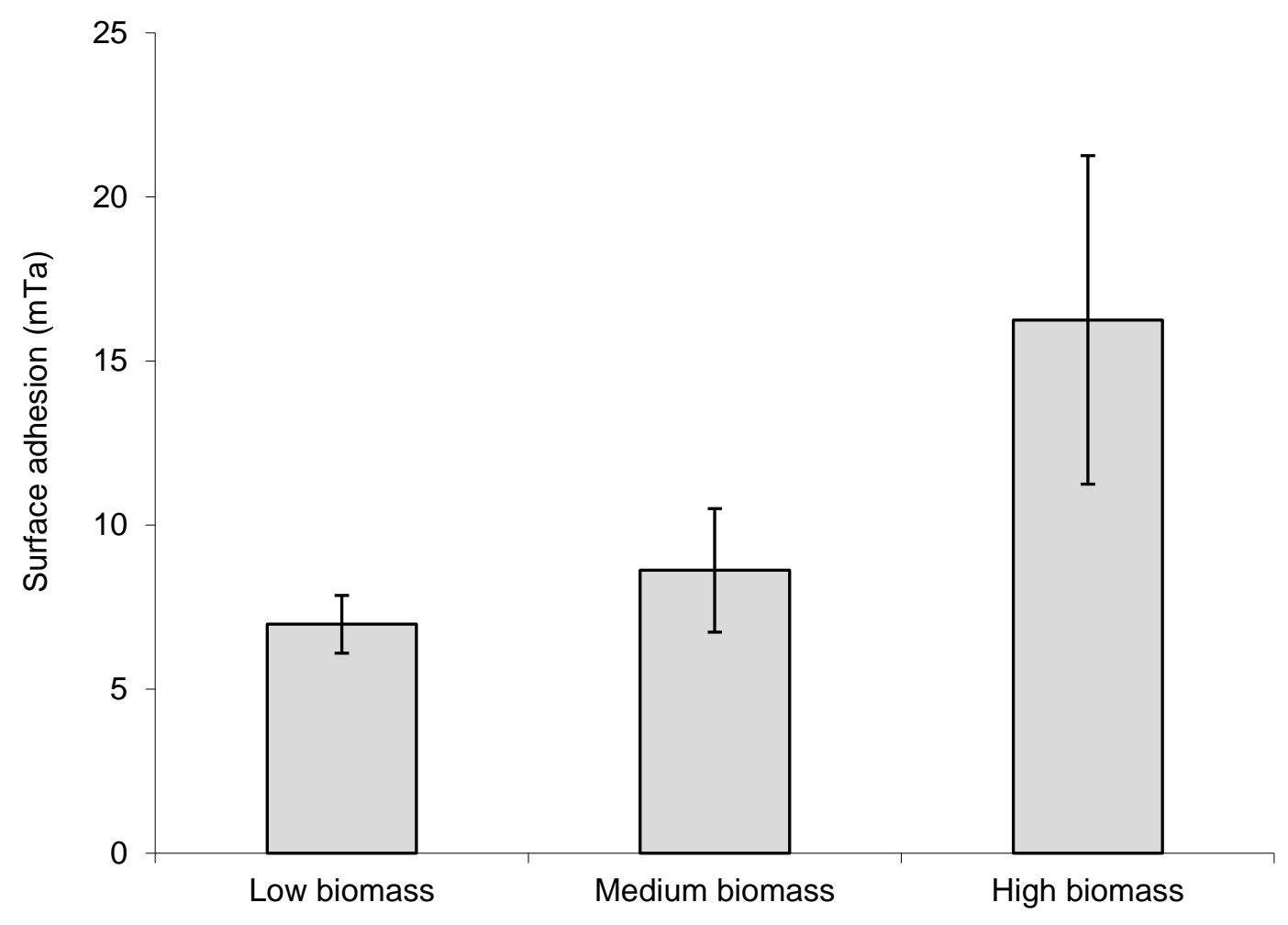

Figure 4: sediment cohesion (mTa; mean $\pm \mathrm{SD}$ ) in sites with low, medium and high biomass of purple sulfur bacteria, in Roscoff Aber Bay (see fig 2). Measurements were performed using a Magnetic Particle Inducer (MagPI), a d evice recently developed by Larson et al. (2009). 


\begin{tabular}{|c|c|c|c|}
\hline Pigments and in vivo spectral signatures & Type of measurement & Type of microbial community & Reference \\
\hline $\begin{array}{l}\text { BChla (800-810, 860-880), BChlc (750), Car (450- } \\
550), \text { PC (620) }\end{array}$ & Reflectance & $\begin{array}{l}\text { Microcoleus chthonoplastes, Chromatium sp., } \\
\text { Thiocapsa sp., Chloroflexus }\end{array}$ & Kühl \& Jørgensen (1992) \\
\hline $\begin{array}{l}\text { BChld \& BChle (720), BChla (835), Chla (680), } \\
\text { PE }(560,570) \text {, PC }(625,630)\end{array}$ & Absorbance & Chromatium, Thiopedia, Chloronema & Steenbergen \& Korthals (1982) \\
\hline Bchla $(370,830)$, Oke $(520)$ & Absorbance & Thiocapsa roseopersicina & Massé et al. (2002) \\
\hline Bchla $(805,860,880)$, Spi $(480,520,550)$ & Absorbance and reflectance & Thiocapsa roseopersicina & Gitelson et al. (1999) \\
\hline $\begin{array}{l}\mathrm{BChl}(800,801,804,806,808,835,837,862,865 \\
867,868,870,879)\end{array}$ & Absorbance & $\begin{array}{c}\text { Review about aerobic anoxygenic phototrophic } \\
\text { bacteria }\end{array}$ & Yurkov \& Csotonyi (2009) \\
\hline BChla $(800,850,890)$, PB $(620)$, & Reflectance & ----------- & Wiggli et al. (1999) \\
\hline $\begin{array}{l}\text { BChla (790-810,865, 830-880), Chla (675), Chlc } \\
\text { (630-635), PC (620), PB (560-620), }\end{array}$ & Reflectance & $\begin{array}{c}\text { Sediment biofilm, Cyanobacteria, diatoms and } \\
\text { purple sulfur bacteria }\end{array}$ & Kühl et al. (1994) \\
\hline Chla (675), Chlc (623), DD (500), Fuco (550) & Reflectance & Diatom biofilms & Méléder et al. (2003) \\
\hline $\begin{array}{l}\text { BChla }(807,845), \text { BChlc }(745-750), \text { Chla }(440, \\
675), \text { PC }(625)\end{array}$ & Absorbance & $\begin{array}{l}\text { Sediment cyanobacterial mat, purple and green } \\
\text { photosynthetic bacteria }\end{array}$ & Kühl \& Fenchel (2000) \\
\hline $\begin{array}{l}\text { Chla }(422,659,680), \text { Car }(422,448,478), \text { Myxo } \\
(508), \text { PB }(534,570,594,628)\end{array}$ & Reflectance & Sediment biofilm (cyanobacterial mat) & Andréfouet et al. (2003) \\
\hline $\begin{array}{l}\text { Alo (649), Chla (412, 441, 623, 682), Chlb (466), } \\
\text { Fuco (525, 540-548,) PE (574) }\end{array}$ & Reflectance & $\begin{array}{l}\text { Rocky shore biofilm, diatoms with } \\
\text { cyanobacteria }\end{array}$ & Murphy et al. (2005) \\
\hline $\begin{array}{l}\text { Chla (422, 444, 676), Chlb \& Chlc (468), Fuco \& } \\
\text { Per (672), PE (572), PC (620), Zea, lut, ß-car \& }\end{array}$ & Reflectance, & Sediment biofilm & Stephens et al. (2003) \\
\hline $\mathrm{DD}(492)$ & & & \\
\hline $\begin{array}{l}\text { Bchlc (732), Chla (440, 680), Chlb (650-655), } \\
\text { Chld (710-712), PE (576), PC (626), }\end{array}$ & Hyperspectral imaging & Bacterial mat under didemnid ascidian & Kühl \& Polerecky (2008) \\
\hline
\end{tabular}

Table 1: in vivo pigment spectral "signatures" collected from available references. Numbers between brackets refer to the absorption features of each pigment. Emphasis was given to references where bacteriochlorophyll samples were found. Alo- alloxanthin, BChl- bacteriochlorophyll, $B$-car- $B$-carotene, BChlabacteriochlorophyll $a, \mathrm{BChl} c$-bacteriochlorophyll $c$, BChld -bacteriochlorophyll $d$, BChle -bacteriochlorophyll $e$, Car- carotenoides, Chla-chlorophyll $a$, Chlb- chlorophyll $b$, Chlc- chlorophyll $c$, Chld- chlorophyll $d$, DD- diadinoxanthin, Fuco- fucoxanthin, Lut- lutein, Myxo- myxoxantophyll, Oke - Okenone, PC- phycocianin, PB- phycobilin pigments, PE- phycoerythrin, Per- peridinin, Spi - Spirilloxanthin, Zea- zeaxanthin 